\title{
Competition in the Indian Banking Sector: A Panel Data Approach
}

\author{
Zhiheng Li ${ }^{1}$, Shuangzhe Liu ${ }^{1}$, Fanda Meng ${ }^{1}$ and Milind Sathye ${ }^{2, * * 1}$ \\ 1 Faculty of Science \& Technology, University of Canberra, Canberra, ACT 2617, Australia \\ 2 Faculty of Business, Government and Law, University of Canberra, Canberra, ACT 2617, Australia \\ * Correspondence: Milind.Sathye@canberra.edu.au; Tel.: +61-2-6201-5489
}

Received: 5 July 2019; Accepted: 17 August 2019; Published: 22 August 2019

\begin{abstract}
The paper aims to assess the level of competition in the Indian banking sector overall as well as within the three groups of banks: foreign owned, state owned (public sector), and privately owned. We use panel data for the period from 2005-2018. We found that the overall competition in the Indian banking sector is strong, although there are differences by type of bank ownership. The Indian banking market continues to be characterized by monopolistic competition. The various policy measures taken by the Indian government in recent years appear to have helped boost competition. A policy suggestion would be to further liberalize the banking sector for foreign investment.
\end{abstract}

Keywords: competition; Indian banking sector; panel data

\section{Introduction}

This paper aims to assess the competitive conditions in the Indian banking sector overall and within the three sets of banks: state-owned, foreign-owned and privately-owned. The research is motivated by the following: First, though there is a vast literature on banking competition in the US and Europe, India, the 6th largest economy in the world (IBEF 2019a), has received limited attention. Second, we use the most recent panel data for the years 2005-2018 to study competition in the Indian banking sector and analyze the competition by bank ownership type. Third, given the importance of India in the world economy and the size of its banking sector, and the liberalized foreign investment policy, several international banks are contemplating entry in India's banking sector. While competition is generally considered to be robust, issues like market dominance of public sector banks, consumer reluctance to switch, and a high proportion of un-provided non-performing assets continue to be a drag on the banking system. Finally, we extend the methodology proposed by Apergis et al. (2016) and apply it to the Indian banking sector.

The context of India is important because the banking sector continues to play an important role in the Indian economy and contributes around 3\% of India's GDP growth (Debnath and Shankar 2008). Second, several reforms were initiated by the Modi government to restore the health of the banking institutions. These included the introduction of Insolvency and Bankruptcy Code 2016 and recapitalization of public sector banks ${ }^{1}$. Whether these measures initiated by the Modi government after it came to power in 2014, improved competitive conditions in the Indian banking sector is an issue that has not been examined so far. We fill this gap.

1 As noted by Mohapatra and Jha (2018), the Modi government infused Rs 66.90 billion in the public sector banks during 2014-2015 and Rs 250 billion each in the years 2015-2016 and 2016-2017. It further intended to infuse Rs 880 billion in 2017-2018. 
The Indian commercial banking sector consists of 27 public sector banks, 21 private sector banks, and 49 foreign banks. There are also 56 regional rural banks, 1562 urban cooperative banks, and 94,384 rural cooperative banks. The total loans extended by commercial banks alone amounted to Rs $93,751.17$ billion (US\$1299.39 billion), and deposits amounted to Rs $120,818.92$ billion (US $\$ 1866.22$ billion) by the end of first quarter of 2019, while the assets of public sector banks alone were US $\$ 1557.04$ billion in 2018 (IBEF 2019b).

We make following important contributions to the literature:

(a) We compare the competitive conditions among the public, private, and foreign banks, which has not been attempted in prior studies on Indian banking except by Prasad and Ghosh (2007);

(b) We use panel data analysis similar to Apergis et al. (2016) to bring additional insights not found in prior studies;

(c) We confirm the findings of prior studies on competition in Indian banking, using a different methodology and latest available data.

Besides these contributions to the literature, the study could also help inform policy and strategic managerial decisions, especially for banks considering to enter or expand in the flourishing Indian banking market.

The paper is organized as follows. Section 2 presents the literature review. The methodology is presented in Section 3. Section 4 presents the results and discussion, and Section 5 concludes.

\section{Theory and Literature Review}

The theory of contestable markets (Baumol 1982) provides the theoretical rationale for competition studies. The theory posits that in a contestable market there are no entry or exit barriers. Consequently, the market reaches stability and equilibrium, whatever be the structure-monopoly, oligopoly or duopoly-provided the market outcome is sustainable.

In the literature, competition is measured by either the structural (non-formal) approach or the non-structural (formal) approach. The structure-conduct-performance (SCP) paradigm is used as the framework in the structural approach. It posits that concentration of market power can lead to lower deposit rates and higher lending rates thereby enabling banks to earn monopolistic profits. The Herfindahl-Hirschman index (HHI) is used to examine the relationship between concentration and market power. To obtain HHI, either the deposits or total assets or total loans for each bank are squared and thereafter summed up. The three or five-firm concentration ratio is calculated which depicts the state of market concentration.

The alternative efficient structure hypothesis (ESH) posits that it is not market power that brings higher profits but the efficiency gains that follow market concentration. In the non-structural approach, generally two methods have been used: Bresnahan (1982) model and the Panzar and Rosse (1987) model. Bresnahan (1982) and Lau (1982) used aggregate industry data and a parameter to proxy market power and estimated a simultaneous equation model. Researchers such as Shaffer (1993) and Bikker and Haaf (2002) have used this model.

The Panzar and Rosse (1987) model examines how the changes in factor input prices affect the revenue of a bank. As the model uses bank-specific data, it captures unique bank characteristics. Many studies have used the Panzar and Rosse $H$ statistic to assess the competitive conditions in the banking market in US, Europe, and other countries. These studies (for example, Berg and Kim 1998; Bikker and Groeneveld 2000; Shaffer 2002; Bikker and Haaf 2002; Beck et al. 2006), generally found that banks operated in a monopolistic competition. When a multi-country study was conducted by Gutiérrez de Rozas (2007), it was found that US Banks were more competitive compared to the European banks. Claessens and Laeven (2004) computed $H$ statistic for the years 1994-2001 for 50 countries-both developed and developing - and found that monopolistic competition prevailed in the banking markets of these countries. Bikker and Spierdijk (2008) similarly found monopolistic competition in the banking market of EU countries. Fosu (2013) in the context of a sub-regional study 
of banking competition in Africa found that the banking markets could be described by monopolistic competition. Barros and Mendes (2016) found that in Angola, the banking market was monopolistic.

Similarly, Anginer et al. (2012) used data for 63 countries over 1997-2009 and found a positive relationship between competition and systemic stability. The majority of the other studies on banking competition also suggest that generally the market is characterized by monopolistic competition (Apergis et al. 2016). In such a market, as suggested by the theory of monopolistic competition, firms have little to no control over the market price and, as such, compete on the basis of product differentiation. Consequently, to improve profitability and to compete in the market, managers have to resort to strategies like mergers, acquisitions, improving operational cost efficiency, asset and liabilities diversification, and increasing non-interest revenue (Andrieş and Căpraru 2014). There are many other notable studies on competition in banking (for example, Yüksel et al. 2016, 2018; Dinçer and Yüksel 2018; Dinçer et al. 2019).

Studies on competition in Indian banking are limited. Prasad and Ghosh (2005) computed the Panzar and Rosse $H$-statistic of Indian banks using data of 64 commercial banks for the period 1997-2004 and found that the Indian banking market demonstrated a monopolistic competition. Prasad and Ghosh (2007) used annual data of scheduled commercial banks for the period 1996-2004 and again confirmed the results of their earlier study. Mishra (2011) studied 75 banks classified by ownership-public, private, and foreign - over a period of 1997-2008 using two panel data sets-each of 6 years. They found that the Indian banking sector is characterized by monopolistic competition and that liberalization has helped improve its efficiency, productivity and stability. Mishra and Sahoo (2012) studied 59 Indian banks for the years 1999-2000 to 2008-2009 and found a multi-directional and dynamic relationship in the Indian banking sector. Ansari (2012) found that the Indian loan market was monopolistic and that public sector banks and private sector banks were more competitive than foreign banks. Dutta (2013) analyzed the degree of competition in the Indian banking sector for the period 1997-1998 to 2004-2005 and found that the competitive environment improved following banking reforms and that competition has become more severe. Apergis (2015) in a study of 21 emerging market economies, that included India, found that these markets were characterized by monopolistic competition. Rakshit and Bardhan (2019) measured the competitive conditions in India using a sample of 70 commercial banks over the period 1996-2016. It was found that public sector banks experienced a relatively higher degree of competition compared to private and foreign banks. Like other emerging markets, Sinha and Sharma (2016) found that the Indian banking market is characterized by monopolistic competition. Arrawatia et al. (2019) studied banking competition in India for the period 1996-2016 using the learner index approach and confirmed the monopolistic competitive conditions.

The present study improves on prior studies in the following ways:

(a) We use more recent data, that is, for the years, 2005-2018;

(b) We examine the competitive conditions faced by ownership group of banks;

(c) We use the Panzar and Rosse (1987) model as extended by Apergis et al. (2016) and apply it to the Indian context and provide new insights not available hitherto in the literature.

\section{Data and Method}

In this section, the data and method have been described.

\subsection{Data}

The required data was obtained from the Reserve Bank of India website where yearly data is available for the years 2005-2018. The banks for which data was missing on some of the variables were dropped from the analysis. Some banks merged during the period, and new banks entered the Indian banking market. Consequently, it is unbalanced panel data. The total observations used for the analysis were 784 . 


\subsection{Method}

The Panzar and Rosse $H$ statistic is typically used in the literature to test the theory of competitive conditions in the market. To determine the market structure, a four-step methodology is followed; that is, a log-linear form regression is estimated, and factor input elasticities are calculated; these are summed up to give the $H$ statistic, and then the criteria as indicated below is used to determine the competitiveness of the market. The elasticities are calculated by estimating a reduced form revenue equation involving a vector of input prices and other control variables. The reduced form revenue equation of the Panzar and Rosse (1987) variety is written as below:

$$
\ln G R=a+\sum_{i=1}^{n} B_{i} \ln \omega_{i}+\sum_{i=1}^{n} \gamma_{i} \ln C F_{i}+\varepsilon
$$

where GR refers to gross revenue, $\omega_{i}$ refers to the $i$ th input factor, and $C F$ refers to firm-specific control factors. The equation for computing $H$ statistic is as below:

$$
H=\sum_{i=1}^{k} B_{i}
$$

where $k=3$ refers to the three factor input elasticities.

Panzar and Rosse (1987) show that when $H$ is negative the market is monopolistic. If it is 1 , the market is perfectly competitive and in long-run equilibrium, and when the $H$ lies between 0 and 1 , it is considered to be monopolistically competitive market.

Apergis et al. (2016), however, point out that the method is not useful for comparing the competition between large and small banks or between banks by ownership type-foreign vs. domestic, for example. Furthermore, as Bikker and Spierdijk (2008) and Bikker et al. (2012) show, the use of both scaled and unscaled price or revenue function in modelling, as most prior studies have done, can lead to unreliable estimation of the $H$ statistic. To overcome these limitations of prior studies, Apergis et al. (2016) used both scaled and unscaled price and revenue equations to estimate $H$ statistic in the context of European banking.

Following from Molyneux et al. (1994), Bikker and Haaf (2002), Bikker and Spierdijk (2008), Anginer et al. (2012), and Apergis et al. (2016), we estimate five reduced-form revenue equations as below:

$$
\begin{aligned}
& \ln \left(P_{i t}\right)=\begin{aligned}
a \\
+
\end{aligned} \beta_{1} \ln \left(\text { FUND }_{i t}\right)+\beta_{2} \ln \left(\text { WAGE }_{i t}\right)+\beta_{3} \ln \left(C A P_{i t}\right) \\
&+\gamma_{1} \ln \left(L E V_{i t}\right)+\gamma_{2} \ln \left(\text { RISK }_{i t}\right)+\gamma_{3} \ln \left(\text { SIZE }_{i t}\right)+\epsilon_{i t} \\
& \ln \left(R O A_{i t}\right)= a+\beta_{1} \ln \left(F U N D_{i t}\right)+\beta_{2} \ln \left(W A G E_{i t}\right)+\beta_{3} \ln \left(C A P_{i t}\right) \\
&+\gamma_{1} \ln \left(L E V_{i t}\right)+\gamma_{2} \ln \left(R I S K_{i t}\right)+\gamma_{3} \ln \left(S I Z E_{i t}\right)+\epsilon_{i t} \\
& \ln \left(Z_{i t}\right)= a+\beta_{1} \ln \left(F U N D_{i t}\right)+\beta_{2} \ln \left(W A G E_{i t}\right)+\beta_{3} \ln \left(C A P_{i t}\right) \\
&+\gamma_{1} \ln \left(L E V_{i t}\right)+\gamma_{2} \ln \left(\text { RISK K }_{i t}\right)+\gamma_{3} \ln \left(S I Z E_{i t}\right)+\epsilon_{i t}
\end{aligned}
$$

Since Bikker et al. (2012) point out that scaled revenue and price functions as above are likely to over-estimate banking competition, we estimate $H$ indices generated by following unscaled models as a check of robustness.

$$
\begin{aligned}
\ln \left(\text { GIR }_{i t}\right)= & a+\beta_{1} \ln \left(\text { FUND }_{i t}\right)+\beta_{2} \ln \left(\text { WAGE }_{i t}\right)+\beta_{3} \ln \left(C A P_{i t}\right) \\
& +\gamma_{1} \ln \left(L E V_{i t}\right)+\gamma_{2} \ln \left(\text { RISK }_{i t}\right)+\gamma_{3} \ln \left(\text { SIZE }_{i t}\right)+\epsilon_{i t} \\
\ln \left(\text { TR }_{i t}\right)= & a+\beta_{1} \ln \left(F U N D_{i t}\right)+\beta_{2} \ln \left(\text { WAGE }_{i t}\right)+\beta_{3} \ln \left(C A P_{i t}\right) \\
& +\gamma_{1} \ln \left(L E V_{i t}\right)+\gamma_{2} \ln \left(\text { RISK }_{i t}\right)+\gamma_{3} \ln \left(S I Z E_{i t}\right)+\epsilon_{i t}
\end{aligned}
$$

In the above equations, $a$ and $\epsilon_{i t}$ are the intercept and the error term respectively. The other variables and their measures are tabulated below in Table 1. 
Table 1. Variables and their measurements.

\begin{tabular}{cl}
\hline Variable & \multicolumn{1}{c}{ Description } \\
\hline$P_{i t}$ & Ratio of gross interest revenue to total assets for bank $i$ at time $t$, which is a proxy for loan prices \\
\hline$F U N D_{i t}$ & $\begin{array}{l}\text { Ratio of interest expenses to total deposits and money market funds for bank } i \text { at time } t \text {, which is a } \\
\text { proxy for average funding cost }\end{array}$ \\
\hline$W A G E_{i t}$ & Ratio of personnel expenses to total assets for bank $i$ at time $t$, which is a proxy for wage rate \\
\hline$C A P_{i t}$ & $\begin{array}{l}\text { Ratio of operating and administrative expenses to total assets for bank } i \text { at time } t \text {, which is a proxy } \\
\text { for the price for physical capital employed }\end{array}$ \\
\hline$L E V_{i t}$ & Ratio of equity to total assets for bank $i$ at time $t$, which is a proxy for the leverage \\
\hline$R I S K_{i t}$ & Ratio of net loans to total assets for bank $i$ at time $t$, which is a proxy for the credit risk \\
\hline$S I Z E_{i t}$ & Total assets \\
\hline$R O A_{i t}$ & Represents pre-tax return on assets \\
\hline$Z_{i t}$ & Ratio of total revenue to total assets for bank $i$ at time $t$ \\
\hline$G I R_{i t}$ & Gross interest revenue \\
\hline$T R_{i t}$ & Total revenue \\
\hline
\end{tabular}

The sum of three elasticities yields the $H$ statistic in Equations (1) and (3) above.

The data for all variables is annual and the variables are in their natural logarithms. The data are reported in Indian currency (Rupees). Conversion into US dollars or other foreign currency is required in a multi-country study.

Summary statistics of the variables included in the model are presented in Tables A1 and A2 in the Appendix A. As can be seen from the standard deviation of the variables, the data do not depict any major variation from the mean. Similarly, the values of skewness and kurtosis suggest that the data are not normally distributed.

The level of competition has been assessed using fixed effects panel GLS estimator, and robustness has been tested by OLS estimator advocated by Pedroni (2000).

\section{Results and Discussion}

We present and discuss the results of our study in this section.

\subsection{Stationarity Test}

The results of unit root test are presented in Table A3. The results do not support the presence of unit root. Consequently, the levels data were used for estimation purposes.

\subsection{Estimation}

We present the results of estimation of the five models as indicated earlier in Table A4. The profit, ROA, and Z columns refer to scaled regression results, while GIR and TR are unscaled regression results representing Equations (1) to (3) and (4) and (5), respectively.

Table A4 presents the results of OLS, fixed effects, and random effects regressions for all banks as well as separately for the foreign banks group, public sector banks groups, and private-sector banks group. As the tables are large, these have been presented in the Appendix A.

As can be seen from the tables, the CAP variable has a smaller (co-efficient) value than FUND and WAGE variables in Equation (1) (profit equation). It is indicative of the fact that excess physical capital (such as the number of branches) does not result in abnormal revenue. In the ROA test and in the $Z$ test, the CAP variable has a larger value than FUND and WAGE variables whichever regression method-OLS, fixed effects, or random effects-is used. It signifies that return on assets is impacted by input prices. The robustness of models 1 to 3 has been checked by Equations (4) and (5) - the GIR and TR columns in Table A4. The high R squared values in OLS of these equations indicate high collinearity. 
Table A4 also shows the values of VIF. It can be seen that the values are much below 10 . VIF values above 10 are indicative of multi-collinearity (Hair et al. 2006).

The $H$ index (which is the sum of elasticities in Equations (1) to (3)) is presented in Table A5 (see the Appendix A).

From Table A5, it can be seen that the $H$ statistic for all banks in India for all the years of the study stood at 0.47 , which indicates that monopolistic competition prevailed. For the public sector banks group, private-sector banks group, and the foreign banks group, the $H$ statistic was $0.50,0.65$, and 0.46 , respectively, which suggests that private sector banks groups were more competitive as compared to the other two groups, and the foreign banks group was the least competitive amongst the three groups. The empirical results of this study are similar to those of prior studies (such as Claessens and Laeven 2004; Casu and Girardone 2006; Gutiérrez de Rozas 2007; Prasad and Ghosh 2007; Ansari 2012; Dutta 2013) and provide evidence of monopolistic competition.

Prasad and Ghosh (2007) analyzed scheduled commercial banks data for the period 1996-2004, and found that the $H$ statistic was 0.20 for public sector banks. In our study, the value stands at 0.50 which indicates increased competition in the public sector banks group. Similarly, for the foreign banks and private bank groups, these authors reported $H$ statistic of 0.45 and 0.55 , respectively. We found the $H$ statistic for these group to be 0.46 and 0.65 , respectively, indicating increased competition in all the three groups. Zhao et al. (2010) who examined the Indian lending market found that during 1998-2004 (study years) competition was stronger. Ansari (2012) using data for the period 1996-2011 found that the concentration in public sector banks and private sector banks was lower than in foreign banks. Our results are similar.

The competitive conditions in the Indian banking market are different from those in other developing countries. In Ghana, for example, banking is highly concentrated (Adjei-Frimpong et al. 2016). Studies in Africa and Angola by Fosu (2013) and Barros and Mendes (2016), respectively, found that the African banking market demonstrated monopolistic competition while the Angolan banking market was monopolistic.

The Government of India has initiated a program of merger of public sector banks to form four major banks in that sector to enable them to be internationally competitive. Accordingly, three major public sector banks, viz., Dena Bank, Vijaya Bank, and Bank of Baroda were merged in 2018. The merger will become effective from 1 April 2019. More mergers are on the cards as the government wants to create large banks that could compete globally. The mergers are unlikely to adversely impact competition in the sector as a whole. The Indian banking sector is, however, sagged with some major problems such as bad loans, cyber threats, and bank frauds, observed the Financial Stability Report of the Reserve Bank of India (RBI). The Report found that the average bad loans of public sector banks constituted $75 \%$ of their net worth and were squeezing banks' profitability and capital positions, endangering the health of the banking system.

\section{Conclusions}

Typically, the three firm or five firm concentration index or the HHI are used to assess competition in the banking market. However, these ratios and indices may not be appropriate to assess competition, given the information asymmetries in corporate borrowing, switching costs in retail lending, and network externalities in payment systems (Apergis et al. 2016).

The present study aimed to assess the competition in the Indian banking sector overall and within the three bank groups by ownership, that is, state-owned, foreign-owned, and privately-owned. Unbalanced panel data for the period 2005-2018 available at the Reserve Bank of India website was used. Panzar and Rosse $H$ statistic was computed. Following from Apergis et al. (2016), we empirically estimated the level of banking competition. The results confirm that though the Indian banking market is characterized by monopolistic competition, it has witnessed significant reduction in concentration compared to the results reported by prior studies. The results suggest that the measures taken by the Modi government since 2014 have contributed to increasing competition in the banking sector. 
These findings are similar to those by Dutta (2013) who found that banking reforms have helped increase competition in Indian banking.

A policy suggestion emanating from this research would be that the Indian government needs to further liberalize foreign direct investment policy in the banking sector to reap the advantages of competition. As already indicated, the banking sector continues to be dominated by the public sector banks. This is unlikely to change given the geographical spread of these banks across the country.

Future studies could explore the banking competition in India vis-a-vis that of other Asian countries or the BRICS countries so that a comparative picture can emerge. The lessons from Indian banking liberalization over the years could be helpful for other countries in the region if analysis similar to that presented in Table A4 could be attempted for each of the bank ownership groups.

Author Contributions: Conceptualization, M.S.; methodology, S.L. and Z.L.; software, S.L. and Z.L.; validation, S.L., Z.L. and F.M.; formal analysis, Z.L. and F.M.; original draft preparation, M.S.; writing, M.S.; visualization, Z.L. and F.M.; supervision, M.S. and S.L.; project administration, S.L. and M.S.

Funding: This research received no external funding.

Acknowledgments: The authors are very grateful to the anonymous referees whose insights considerably helped improve the quality of the paper.

Conflicts of Interest: The authors declare no conflict of interest.

\section{Appendix A}

Table A1. Descriptive statistics for dependent variable.

\begin{tabular}{cccccc}
\hline Variables & $\mathbf{P}$ & ROA & $\mathbf{Z}$ & GIR & TR \\
\hline Observations & 784 & 784 & 784 & 784 & 784 \\
Mean & -2.8 & -3.85 & -2.39 & 9.76 & 9.98 \\
Max & -1 & -2 & -1 & 15 & 15 \\
Min & -4 & -6 & -3 & 2 & 4 \\
SD & 0.41 & 0.58 & 0.49 & 2.58 & 2.44 \\
Variance & 0.17 & 0.33 & 0.24 & 6.66 & 5.99 \\
Skewness & 1.35 & 0.39 & -0.42 & -0.87 & -0.74 \\
Kurtosis & 3.68 & 4.67 & 1.26 & 2.97 & 2.62 \\
\hline
\end{tabular}

Table A2. Statistics for control variables.

\begin{tabular}{ccccccc}
\hline Variables & FUND & WAGE & CAP & LEV & RISK & SIZE \\
\hline Observations & 784 & 784 & 784 & 784 & 784 & 784 \\
Mean & -3 & -4.8 & -3.94 & -4.46 & -0.75 & 12.46 \\
Max & 0 & -3 & -2 & 0 & 0 & 17 \\
Min & -7 & -6 & -5 & -12 & -6 & 6 \\
SD & 0.52 & 0.55 & 0.43 & 2.05 & 0.7 & 2.5 \\
Variance & 0.27 & 0.31 & 0.19 & 4.22 & 0.49 & 6.23 \\
Skewness & -2.1 & 0.66 & 0.95 & -0.09 & -2.15 & -0.77 \\
Kurtosis & 20 & 3.76 & 7.83 & 3.09 & 15.15 & 2.74 \\
\hline
\end{tabular}


Table A3. Panel unit root test results. (A) ALL BANKS; (B) PUBLIC BANKS; (C) PRIVATE BANKS; (D) FOREIGN BANKS.

(A)

\begin{tabular}{ccc}
\hline & Levin-Lin-Chu (lag = 1) & Harris-Tzavalis \\
\hline Dependent Variable & & \\
P & -3.1146 & 0.3823 \\
ROA & $(0.0009)$ & $(0.0000)$ \\
& -1.1360 & 0.3120 \\
Z & $(0.1280)$ & $(0.0000)$ \\
& -5.1795 & 0.3077 \\
GIR & $(0.0000)$ & $(0.0000)$ \\
& -8.4448 & 0.7775 \\
TR & $(0.0000)$ & $(0.2053)$ \\
Control Variable & -8.0946 & 0.7952 \\
FUND & $(0.0000)$ & $(0.4308)$ \\
& 3.2552 & 0.4119 \\
WAGE & $(0.9994)$ & $(0.0000)$ \\
CAP & -2.0179 & 0.4337 \\
& $(0.0218)$ & $(0.0000)$ \\
LEV & 8.7533 & 0.3354 \\
& $(1.0000)$ & $(0.0000)$ \\
RISK & -5.0416 & 0.6355 \\
& $(0.0000)$ & $(0.0000)$ \\
SIZE & -20.9664 & 0.5021 \\
& $(0.0000)$ & $(0.0000)$ \\
& -7.1205 & 0.8119 \\
& $(0.0000)$ & $(0.6682)$ \\
\hline
\end{tabular}

Notes: The null and alternative hypotheses are H0: Panels contain unit roots, Ha: Panels are stationary. The $p$-values are indicated in the brackets. Most of them are smaller than a significant level of 0.05 , indicating that we can reject the corresponding $\mathrm{H} 0$ and conclude most panels to be stationary.

(B)

\begin{tabular}{ccc}
\hline & Levin-Lin-Chu (lag = 1) & Harris-Tzavalis \\
\hline Dependent Variable & -3.3197 & \\
P & $(0.0005)$ & 0.4091 \\
& 1.4342 & $(0.0000)$ \\
ROA & $(0.9242)$ & 0.431 \\
& -4.8722 & $(0.0000)$ \\
Z & $(0.0000)$ & 0.3175 \\
& -6.1517 & $(0.0000)$ \\
GIR & $(0.0000)$ & 0.7716 \\
& -6.0160 & $(0.2623)$ \\
TR & $(0.0000)$ & 0.779 \\
Control Variable & 29.9577 & $(0.3192)$ \\
FUND & $(1.0000)$ & 0.4667 \\
& -3.3910 & $(0.0000)$ \\
WAGE & $(0.0003)$ & 0.4342 \\
& 10.6714 & $(0.0000)$ \\
CAP & $(1.0000)$ & 0.4677 \\
& -4.8137 & $(0.0000)$ \\
LEV & $(0.0000)$ & 0.6311 \\
& -3.3426 & $(0.0001)$ \\
RISK & $(0.0004)$ & 0.4772 \\
& -5.4441 & $(0.0000)$ \\
SIZE & $(0.0000)$ & 0.8107 \\
& & $(0.5946)$ \\
\hline
\end{tabular}


Table A3. Cont.

(C)

\begin{tabular}{ccc}
\hline & Levin-Lin-Chu (lag = 1) & Harris-Tzavalis \\
\hline Dependent Variable & -1.0061 & \\
P & $(0.1572)$ & 0.4009 \\
ROA & 0.7258 & $(0.0000)$ \\
& $(0.7660)$ & 0.2187 \\
Z & -1.1228 & $(0.0000)$ \\
& $(0.1308)$ & 0.3079 \\
GIR & -3.7480 & $(0.0000)$ \\
& $(0.0001)$ & 0.8342 \\
TR & -4.0813 & $(0.7409)$ \\
Control Variable & $(0.0000)$ & 0.8795 \\
FUND & 2.1392 & $(0.9335)$ \\
& $(0.9838)$ & 0.2952 \\
WAGE & 1.2317 & $(0.0000)$ \\
CAP & $(0.8910)$ & 0.4508 \\
& 11.7123 & $(0.0000)$ \\
LEV & $(1.0000)$ & 0.5500 \\
& -2.6523 & $(0.0000)$ \\
RISK & $(0.0040)$ & 0.6976 \\
& 0.2849 & $(0.0264)$ \\
SIZE & $(0.6121)$ & 0.4711 \\
& -3.0872 & $(0.0000)$ \\
& $(0.0010)$ & 0.8456 \\
& & $(0.8054)$ \\
\hline
\end{tabular}

(D)

\begin{tabular}{ccc}
\hline & Levin-Lin-Chu (lag = 1) & Harris-Tzavalis \\
\hline Dependent Variable & -0.7975 & 0.3112 \\
P & $(0.2126)$ & $(0.0000)$ \\
ROA & -3.8816 & 0.2964 \\
& $(0.0001)$ & $(0.0000)$ \\
Z & -2.4022 & 0.2943 \\
& $(0.0081)$ & $(0.0000)$ \\
GIR & $-4.7150(0.0000)$ & $0.7288(0.0600)$ \\
& $(0.0000)$ & $(0.0600)$ \\
TR & -3.8617 & 0.7213 \\
Control Variable & $(0.0001)$ & $(0.0428)$ \\
FUND & -4.3949 & 0.4286 \\
& $(0.0000)$ & $(0.0000)$ \\
WAGE & -0.5895 & 0.4245 \\
& $(0.2778)$ & $(0.0000)$ \\
CAP & 0.3500 & 0.2827 \\
& $(0.6368)$ & $(0.0000)$ \\
LEV & -0.8784 & 0.6036 \\
& $(0.1899)$ & $(0.0000)$ \\
RISK & -21.1734 & 0.5282 \\
& $(0.0000)$ & $(0.0000)$ \\
SIZE & -3.7125 & 0.779 \\
& $(0.0001)$ & $(0.3231)$ \\
\hline & &
\end{tabular}


Table A4. Regression of control variables. (A) ALL BANKS; (B) PUBLIC BANKS; (C) PRIVATE BANKS; (D) FOREIGN BANKS.

(A)

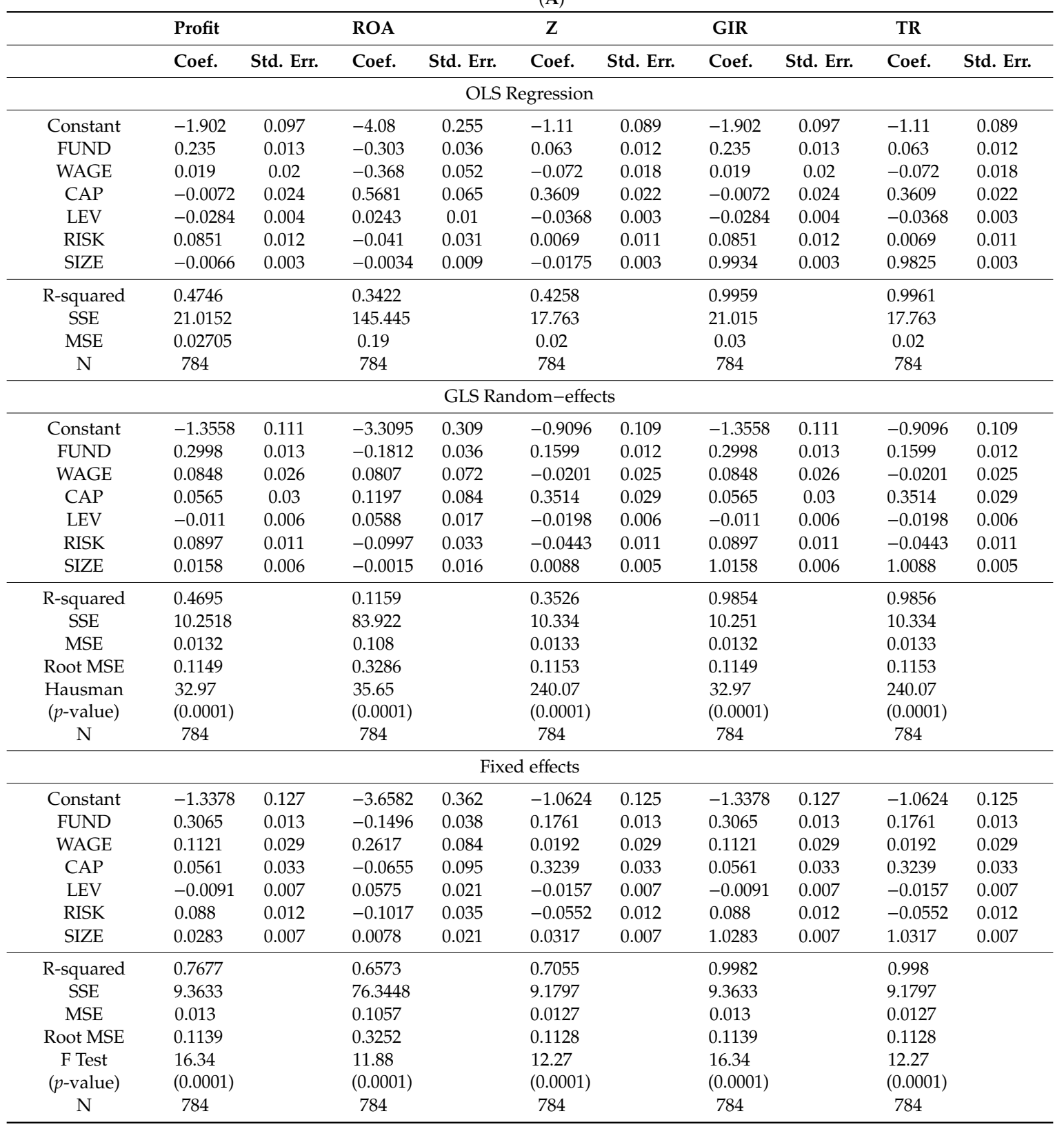

Notes: (1) The null and alternative hypotheses for the Hausman test are H0: Random Effects, Ha: Fixed Effects. The $p$ values in the brackets are smaller than a significant level of 0.05 , indicating that we reject $\mathrm{H} 0$ and conclude to use Fixed Effects models (better than Random Effects models). (2) The null and alternative hypotheses for the F test are H0: No Fixed Effects, Ha: Fixed Effects. The $p$ values in the brackets are smaller than a significant level of 0.05 , indicating that we reject $\mathrm{HO}$ and conclude to use Fixed Effects models (better than OLS models). 
Table A4. Cont.

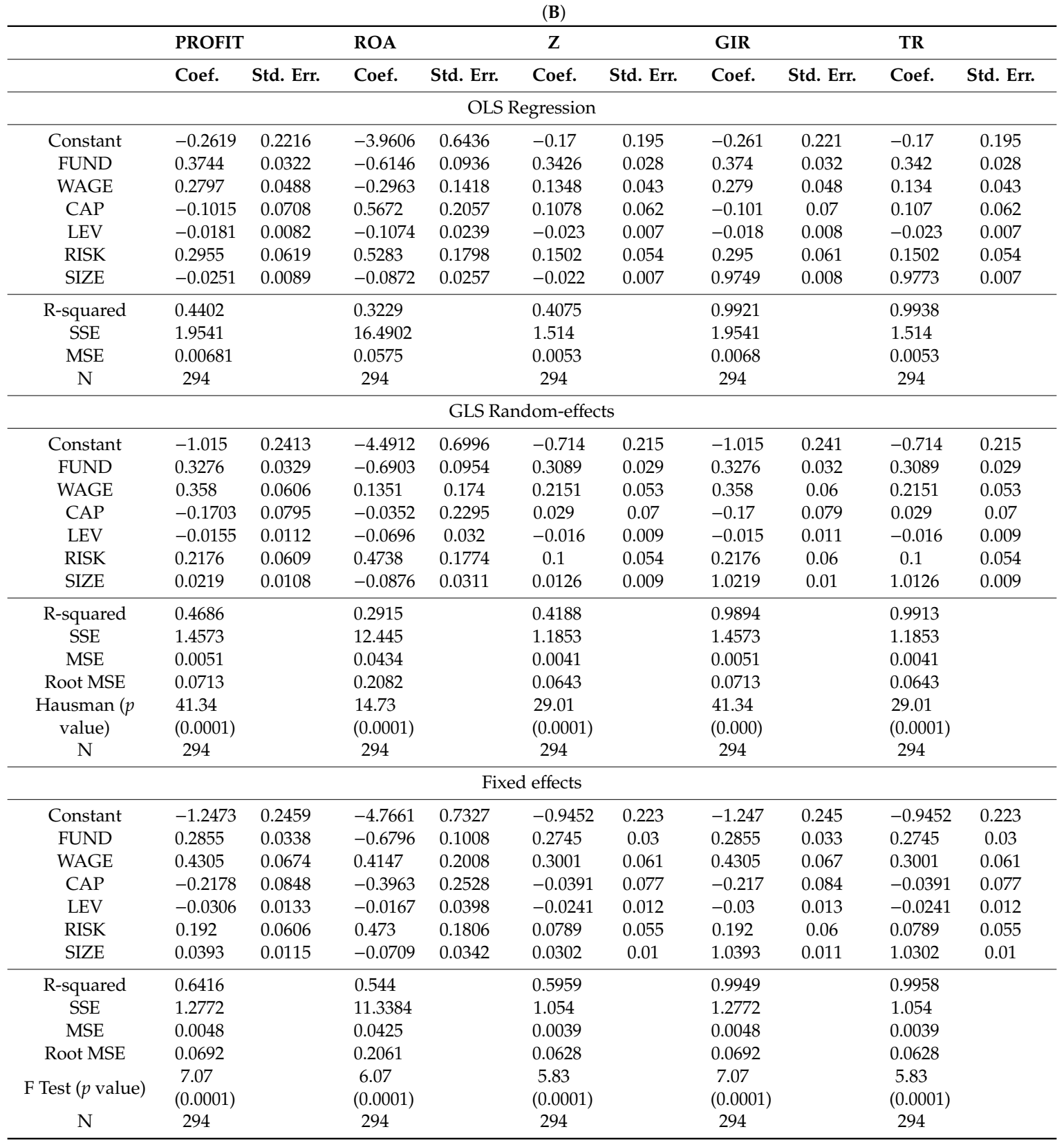


Table A4. Cont.

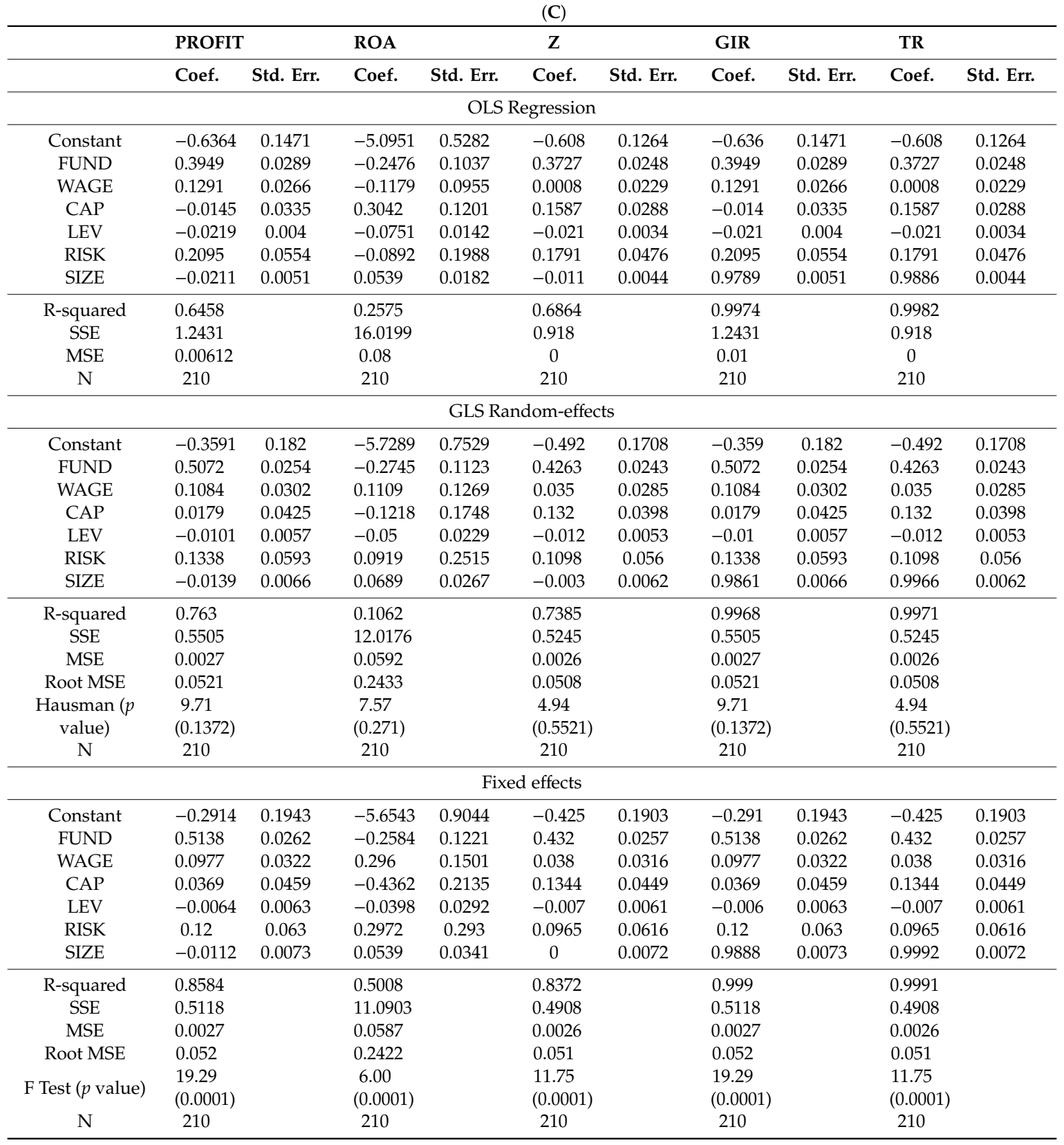


Table A4. Cont.

\begin{tabular}{|c|c|c|c|c|c|c|c|c|c|c|}
\hline \multicolumn{11}{|c|}{ (D) } \\
\hline & \multicolumn{2}{|l|}{ PROFIT } & \multirow{2}{*}{$\begin{array}{l}\text { ROA } \\
\text { Coef. }\end{array}$} & \multicolumn{3}{|c|}{$\mathrm{Z}$} & \multirow{2}{*}{$\begin{array}{c}\text { GIR } \\
\text { Coef. }\end{array}$} & \multicolumn{3}{|c|}{ TR } \\
\hline & Coef. & Std. Err. & & Std. Err. & Coef. & Std. Err. & & Std. Err. & Coef. & Std. Err. \\
\hline Constant & -2.2339 & 0.156 & -4.3354 & 0.402 & -1.0492 & 0.149 & -2.2339 & 0.156 & -1.0492 & 0.149 \\
\hline FUND & 0.2198 & 0.021 & -0.3492 & 0.053 & 0.0393 & 0.02 & 0.2198 & 0.021 & 0.0393 & 0.02 \\
\hline LEV & 0.0146 & 0.011 & 0.0855 & 0.028 & -0.0215 & 0.01 & 0.0146 & 0.011 & -0.0215 & 0.01 \\
\hline RISK & 0.0538 & 0.016 & -0.0471 & 0.043 & -0.0072 & 0.016 & 0.0538 & 0.016 & -0.0072 & 0.016 \\
\hline SIZE & 0.0022 & 0.006 & 0.0419 & 0.017 & -0.0213 & 0.006 & 1.0022 & 0.006 & 0.9787 & 0.006 \\
\hline R-squared & 0.3767 & & 0.2416 & & 0.495 & & 0.992 & & 0.9916 & \\
\hline SSE & 13.225 & & 87.1541 & & 12.0194 & & 13.225 & & 12.0194 & \\
\hline Constant & -1.615 & 0.198 & -2.9805 & 0.506 & -0.6561 & 0.188 & -1.615 & 0.198 & -0.6561 & 0.188 \\
\hline FUND & 0.2816 & 0.02 & -0.1593 & 0.052 & 0.1248 & 0.019 & 0.2816 & 0.02 & 0.1248 & 0.019 \\
\hline WAGE & -0.0083 & 0.05 & 0.0661 & 0.128 & -0.0182 & 0.047 & -0.0083 & 0.05 & -0.0182 & 0.047 \\
\hline CAP & 0.1145 & 0.055 & 0.1337 & 0.141 & 0.3961 & 0.052 & 0.1145 & 0.055 & 0.3961 & 0.052 \\
\hline LEV & 0.0137 & 0.014 & 0.1569 & 0.037 & 0.0039 & 0.013 & 0.0137 & 0.014 & 0.0039 & 0.013 \\
\hline RISK & 0.08 & 0.018 & -0.1246 & 0.046 & -0.0572 & 0.017 & 0.08 & 0.018 & -0.0572 & 0.017 \\
\hline SIZE & 0.0169 & 0.013 & 0.0031 & 0.033 & -0.0037 & 0.012 & 1.0169 & 0.013 & 0.9963 & 0.012 \\
\hline R-squared & 0.4306 & & 0.1469 & & 0.3981 & & 0.9698 & & 0.9673 & \\
\hline SSE & 7.8402 & & 51.22 & & 7.1054 & & 7.8402 & & 7.1054 & \\
\hline MSE & 0.0287 & & 0.1876 & & 0.026 & & 0.0287 & & 0.026 & \\
\hline Root MSE & 0.1695 & & 0.4332 & & 0.1613 & & 0.1695 & & 0.1613 & \\
\hline WAGE & 0.0532 & 0.056 & 0.0813 & 0.146 & 0.0041 & 0.054 & 0.0532 & 0.056 & 0.0041 & 0.054 \\
\hline CAP & 0.1107 & 0.06 & 0.061 & 0.154 & 0.3963 & 0.057 & 0.1107 & 0.06 & 0.3963 & 0.057 \\
\hline LEV & 0.0035 & 0.016 & 0.1711 & 0.042 & 0.0073 & 0.015 & 0.0035 & 0.016 & 0.0073 & 0.015 \\
\hline RISK & 0.0795 & 0.019 & -0.12 & 0.049 & -0.0687 & 0.018 & 0.0795 & 0.019 & -0.0687 & 0.018 \\
\hline SIZE & 0.0397 & 0.018 & -0.0388 & 0.046 & 0.0179 & 0.017 & 1.0397 & 0.018 & 1.0179 & 0.017 \\
\hline R-squared & 0.6708 & & 0.5977 & & 0.733 & & 0.9958 & & 0.9956 & \\
\hline SSE & 7.1387 & & 47.248 & & 6.4944 & & 7.1387 & & 6.4944 & \\
\hline MSE & 0.0281 & & 0.186 & & 0.0256 & & 0.0281 & & 0.0256 & \\
\hline Root MSE & 0.1676 & & 0.4313 & & 0.1599 & & 0.1676 & & 0.1599 & \\
\hline F Tect (n value) & 11.40 & & 11.29 & & 11.37 & & 11.40 & & 24.27 & \\
\hline F lest ( $p$ value) & $(0.0001)$ & & $(0.0001)$ & & $(0.0001)$ & & $(0.0001)$ & & $(0.0001)$ & \\
\hline $\mathrm{N}$ & 280 & & 280 & & 280 & & 280 & & 280 & \\
\hline
\end{tabular}


Table A5. $\mathrm{H}$ statistics and $\mathrm{F}$ tests of $\mathrm{H}=0$ and $\mathrm{H}=1$. (A) ALL BANKS; (B) PUBLIC BANKS; (C) PRIVATE BANKS; (D) FOREIGN BANKS.

(A)

\begin{tabular}{cccccc}
\hline & PROFIT & ROA & Z & GIR & TR \\
\hline H statistic & 0.4747 & 0.0466 & 0.5191 & 0.4747 & 0.5191 \\
Test H $=0$ & & & & & \\
F & 322.0077 & 0.3813 & 394.2126 & 322.0077 & 394.2126 \\
$p$ & 0.0000 & 0.5371 & 0.0000 & 0.0000 & 0.0000 \\
Test H $=1$ & & & & & \\
F & 394.2846 & 159.7540 & 338.1969 & 394.2846 & 338.1969 \\
$p$ & 0.0000 & 0.0000 & 0.0000 & 0.0000 & 0.0000 \\
\hline
\end{tabular}

Notes: (1) Test $\mathrm{H}=0$ : The null and alternative hypotheses are $\mathrm{Ho:} \mathrm{H}=0, \mathrm{Ha}: \mathrm{H} \neq 0$. All $\mathrm{p}$ values are smaller than a significant level of 0.05 , so we reject $\mathrm{Ho}: \mathrm{H}=0$, except that the ROA equation has a $\mathrm{p}$ value of 0.3813 not smaller than 0.05 where we cannot reject $\mathrm{Ho}: \mathrm{H}=0$. (2) Test $\mathrm{H}=1$ : The null and alternative hypotheses are Ho: $\mathrm{H}=1$, Ha: $\mathrm{H} \neq 1$. All $p$ values are smaller than a significant level of 0.05 , so we reject $\mathrm{Ho}: \mathrm{H}=1$.

(B)

\begin{tabular}{cccccc}
\hline & PROFIT & ROA & Z & GIR & TR \\
\hline H statistic & 0.49825 & -0.66117 & 0.5355 & 0.498251 & 0.535525 \\
Test H $=0$ & & & & & \\
F & NA & NA & NA & NA & 2238.4359 \\
$p$ & NA & NA & NA & NA & 0.0000 \\
Test H $=1$ & & & & & \\
F & 31.3958 & 51.3694 & 25.1026 & 31.3958 & 25.1026 \\
$p$ & 0.0000 & 0.0000 & 0.0000 & 0.0000 & 0.0000 \\
\hline
\end{tabular}

Notes: (1) Test $\mathrm{H}=0$ : We use NA as the $\mathrm{F}$ values are close to $\mathrm{F}=0$, and therefore their corresponding $p$ values are close to $p=1 ; \mathrm{H} 0: \mathrm{H}=0$ may NOT be significantly rejected because of NA (or F = 0 and $p=1$ ). (2) Test $\mathrm{H}=1: \mathrm{H} 0: \mathrm{H}$ $=1$ is significantly rejected.

(C)

\begin{tabular}{cccccc}
\hline & PROFIT & ROA & Z & GIR & TR \\
\hline H statistic & 0.648402 & -0.39855 & 0.6045 & 0.648402 & 0.6045 \\
Test H $=0$ & & & & & \\
F & 121.8889 & 15.29983 & 89.34615 & 121.8889 & 89.34615 \\
$p$ & 0.0000 & 0.000128 & 0.0000 & 0.0000 & 0.0000 \\
Test H $=1$ & & & & & \\
F & 93.74074 & 68.00511 & 119.4615 & 93.74074 & 119.4615 \\
$p$ & 0.0000 & $2.71 \times 10^{-14}$ & 0.0000 & 0.0000 & 0.0000 \\
\hline
\end{tabular}

Notes: (1) Test $\mathrm{H}=0: \mathrm{H}<0$ is significant as $\mathrm{H} 0: \mathrm{H}=0$ is rejected. See the main text for how to explain this. (2) Test $\mathrm{H}=1: \mathrm{H} 0: \mathrm{H}=1$ is significantly rejected.

(D)

\begin{tabular}{cccccc}
\hline & PROFIT & ROA & Z & GIR & TR \\
\hline H statistic & 0.460325 & 0.007275 & 0.543523 & 0.460325 & 0.543523 \\
Test H $=0$ & & & & & \\
F & 83.96797 & 0.003226 & 128.4961 & 83.96797 & 128.4961 \\
$p$ & 0.0000 & 0.954752 & 0.0000 & 0.0000 & 0.0000 \\
Test H $=1$ & & & & & \\
F & 115.4128 & 58.99892 & 90.63281 & 115.4128 & 90.63281 \\
$p$ & 0.0000 & $3.42 \times 10^{-13}$ & 0.0000 & 0.0000 & 0.0000 \\
\hline
\end{tabular}

\section{References}

Adjei-Frimpong, Kofi, Christopher Gan, and Baiding Hu. 2016. Competition in the banking industry: Empirical evidence from ghana. Journal of Banking Regulation 17: 159-75. [CrossRef]

Andrieş, Alin Marius, and Bogdan Căpraru. 2014. The nexus between competition and efficiency: The European banking industries experience. International Business Review 23: 566-79. [CrossRef] 
Anginer, Deniz, Asli Demirguc-Kunt, and Min Zhu. 2012. How does competition affect bank systemic risk? Journal of Financial Intermediation 23: 1-26. [CrossRef]

Ansari, Jugnu. 2012. A New Measure of Competition in Indian Loan Market. Mumbai: CAFRAL.

Apergis, Nicholas. 2015. Competition in the banking sector: New evidence from a panel of emerging market economies and the financial crisis. Emerging Markets Review 25: 154-62. [CrossRef]

Apergis, Nicholas, Irene Fafaliou, and Michael L. Polemis. 2016. New evidence on assessing the level of competition in the European Union banking sector: A panel data approach. International Business Review 25: 395-407. [CrossRef]

Arrawatia, Rakesh, Arun Misra, Varun Dawar, and Debasish Maitra. 2019. Bank Competition in India: Some New Evidence Using Risk-Adjusted Lerner Index Approach. Risks 7: 44. [CrossRef]

Barros, Carlos Pestana, and Zorro Mendes. 2016. Assessing the competition in Angola's banking industry. Applied Economics 48: 2785-91. [CrossRef]

Baumol, William J. 1982. Contestable markets: An uprising in the theory of industry structure. American Economic Review 72: 1-15.

Beck, Thorsten, Asli Demirgüç-Kunt, and Ross Levine. 2006. Bank concentration, competition, and crises: First results. Journal of Banking \& Finance 30: 1581-603.

Berg, Sigbjørn Atle, and Moshe Kim. 1998. Banks as multioutput oligopolies: An empirical evaluation of the retail and corporate banking markets. Journal of Money, Credit and Banking 1: 135-53. [CrossRef]

Bikker, Jacob A., and Johannes M. Groeneveld. 2000. Competition and Concentration in the EU Banking Industry. Amsterdam: De Nederlandsche Bank NV, vol. 33, pp. 62-98.

Bikker, Jacob A., and Katharina Haaf. 2002. Competition, concentration and their relationship: An empirical analysis of the banking industry. Journal of Banking $\mathcal{E}$ Finance 26: 2191-214.

Bikker, Jacob A., Sherrill Shaffer, and Laura Spierdijk. 2012. Assessing competition with the Panzar-Rosse model: the role of scale, costs, and equilibrium. Review of Economics and Statistics 94: 1025-44. [CrossRef]

Bikker, Jacob A., and Laura Spierdijk. 2008. How Banking Competition Changed over Time. DNB Working paper, No. 167. Utrecht, The Netherlands: Tjalling C. Koopmans Research Institute.

Bresnahan, Timothy F. 1982. The oligopoly solution concept is identified. Economics Letters 10: 87-92. [CrossRef]

Casu, Barbara, and Claudia Girardone. 2006. Bank competition, concentration and efficiency in the Single European Market. The Manchester School 744: 441-68. [CrossRef]

Claessens, Stijn, and Luc Laeven. 2004. What drives bank competition? Some international evidence. Journal of Money, Credit and Banking 36: 563-83. [CrossRef]

Debnath, Roma Mitra, and Ravi Shankar. 2008. Measuring performance of Indian banks: An application data envelopment analysis. International Journal of Business Performance Management 10: 57-85. [CrossRef]

Dinçer, Hasan, and Serhat Yüksel. 2018. Comparative evaluation of BSC-based new service development competencies in Turkish banking sector with the integrated fuzzy hybrid MCDM using content analysis. International Journal of Fuzzy Systems 20: 2497-516. [CrossRef]

Dinçer, Hasan, Serhat Yüksel, and İpek Tamara Çetiner. 2019. Strategy Selection for Organizational Performance of Turkish Banking Sector with the Integrated Multi-Dimensional Decision-Making Approach. In Handbook of Research on Contemporary Approaches in Management and Organizational Strategy. Philadelphia: IGI Global, pp. 273-91.

Dutta, Nitish. 2013. Competition in Indian Commercial Banking Sector in the liberalized regime: An empirical evaluation. International Journal of Banking, Risk and Insurance 17: 24.

Fosu, Samuel. 2013. Banking Competition in Africa: Sub-Regional Comparative Studies, rev. ed. Discussion Papers in Economics 13/12. Leicester: Division of Economics, School of Business, University of Leicester.

Gutiérrez de Rozas, Luis. 2007. Testing for Competition in the Spanish Banking Industry: The Panzar-Rosse Approach Revisited. Working paper, No. 726. Madrid, Spain: National Central Bank of Spain.

Hair, Joseph F., William C. Black, Barry J. Babin, and Rolph E. Anderson. 2006. Multivariate Data Analysis. Upper Saddle River: Pearson University Press, vol. 6.

India Brand Equity Foundation (IBEF). 2019a. Trends: India Now 6th Largest Economy in the World with High Growth. New Delhi: India Brand Equity Foundation.

India Brand Equity Foundation (IBEF). 2019b. Indian Banking Industry Analysis. New Delhi: India Brand Equity Foundation. 
Lau, Lawrence J. 1982. On identifying the degree of competitiveness from industry price and output data. Economics Letters 10: 93-99. [CrossRef]

Mishra, Arun. 2011. Competition in Banking: The Indian Experience. Paper presented at the International Conference on Economics and Finance Research, Singapore, February 26-28; IPEDR vol. 4.

Mishra, Pulak, and Deepti Sahoo. 2012. Structure, Conduct and Performance in Indian Banking sector. Review of Economic Perspectives 12: 235-64. [CrossRef]

Mohapatra, Amiya, and Srirang Jha. 2018. Bank Recapitalization in India: A Critique of Public Policy Concerns. FIIB Business Review 7: 10-15.

Molyneux, Phil, D. Michael Lloyd-Williams, and John Thornton. 1994. Competitive conditions in European banking. Journal of Banking E Finance 18: 445-59.

Panzar, John C., and James N. Rosse. 1987. Testing for "monopoly" equilibrium. The Journal of Industrial Economics 1: 443-56. [CrossRef]

Pedroni, Peter. 2000. Fully-modified OLS for heterogeneous cointegrated panels. In Advances in Econometrics Nonstationary Panels Panel Cointegration and Dynamic Panels. Edited by Badi H. Baltagi and Chihwa Kao. Amsterdam: Elsevier Science, pp. 93-130.

Prasad, Ananthakrishnan, and Saibal Ghosh. 2005. Competition in Indian Banking. Washington, DC: International Monetary Fund.

Prasad, Ananthakrishnan, and Saibal Ghosh. 2007. Competition in Indian banking: An empirical evaluation. South Asia Economic Journal 8: 265-84. [CrossRef]

Rakshit, Bijoy, and Samaresh Bardhan. 2019. Does bank competition promote economic growth? Empirical evidence from selected South Asian countries. South Asian Journal of Business Studies 8: 201-23. [CrossRef]

Reserve Bank of India (RBI). 2017. Financial Stability Report. Mumbai: Reserve Bank of India.

Shaffer, Sherrill. 1993. A test of competition in Canadian banking. Journal of Money, Credit and Banking 25: 49-61. [CrossRef]

Shaffer, Sherrill. 2002. Conduct in a banking monopoly. Review of Industrial Organization 20: 221-38. [CrossRef]

Sinha, Pankaj, and Sakshi Sharma. 2016. Determinants of bank profits and its persistence in Indian Banks: A study in a dynamic panel data framework. International Journal of System Assurance Engineering and Management 7: 35-46. [CrossRef]

Yüksel, Serhat, Shahriyar Mukhtarov, and Elvin Mammadov. 2016. Comparing the efficiency of Turkish and Azerbaijani banks: An application with data envelopment analysis. International Journal of Economics and Financial Issues 6: 1059-67.

Yüksel, Serhat, Shahriyar Mukhtarov, Elvin Mammadov, and Mustafa Özsarı. 2018. Determinants of Profitability in the Banking Sector: An Analysis of Post-Soviet Countries. Economies 6: 41-49. [CrossRef]

Zhao, Tianshu, Barbara Casu, and Alessandra Ferrari. 2010. The impact of regulatory reforms on cost structure, ownership and competition in Indian banking. Journal of Banking E Finance 34: 246-54. 